\title{
A gamification framework for research productivity enhancement on the higher education institution
}

\author{
Ahmad Sanmorino', Luis Marnisah ${ }^{2}$, Hastha Sunardi ${ }^{3}$ \\ ${ }^{1,3}$ Faculty of Computer Science, Universitas Indo Global Mandiri, Indonesia \\ ${ }^{2}$ Faculty of Economics, Universitas Indo Global Mandiri, Indonesia
}

\section{Article Info \\ Article history: \\ Keywords: \\ Enhancement \\ Framework \\ Gamification \\ Productivity \\ Research}

Received Jul 30, 2020

Revised Mar 15, 2021

Accepted Apr 14, 2021

\begin{abstract}
The condition of research productivity in higher education institutions in Indonesia is still not ideal. Departing from this problem, this paper aims to contribute in the form of a framework used as the main alternative in optimizing research productivity, including the number of publications in higher education institutions. The mechanism proposed is a framework that uses designs derived from games or better known as gamification. Based on the preliminary testing of the proposed framework, it shows that each construct of the framework has a positive impact on research productivity enhancement as the final goal. One of the constructs is Network has a positive impact of 0.415 on Behavior, the Behavior has a positive impact of 0.403 on research productivity enhancement. This also applies to other constructs. Except for the Points that do not have good reliability, it will become homework in future studies.
\end{abstract}

This is an open access article under the CC BY-SA license.

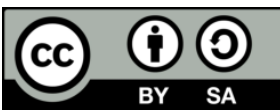

\section{Corresponding Author:}

Ahmad Sanmorino

Faculty of Computer Science

Universitas Indo Global Mandiri

Jl. Jendral Sudirman No.629 Km.4 Palembang, Sumatera Selatan, Indonesia

Email: sanmorino@uigm.ac.id

\section{INTRODUCTION}

The condition of research productivity in Higher Education in Indonesia is still not optimal. Strong motivation is needed to optimize the number of research publications. The motivation can be started from the lecturers themselves, or regulations from the government. The number of publications and the number of lecturers in the Top 10 affiliation in Indonesia shown from the data collected by the Ministry of Research and Technology through Sinta (Science and Technology Index) [1] as shown in Table 1.

Data published on the Sinta database were collected from 2006-2020. The publication ratio for each lecturer per year shown in Table 2. This applies to the assumption that each lecturer has become lecturers or researches since 2006. 
Table 1. Number of publications vs. number of lecturers in the top 10 affiliation in Indonesia (Feb 2020)

\begin{tabular}{ccccc}
\hline No & Affiliation & $\begin{array}{c}\text { Number of } \\
\text { lecturers }\end{array}$ & $\begin{array}{c}\text { Overall number of } \\
\text { publications (Scopus) }\end{array}$ & Overall Sinta score \\
\hline 1 & Universitas Indonesia & 1,682 & 14,561 & 110,323 \\
2 & Institut Teknologi Bandung & 1,349 & 14,393 & 73,165 \\
3 & Universitas Gadjah Mada & 2,300 & 10,421 & 78,635 \\
4 & Institut Teknologi Sepuluh Nopember & 957 & 6,984 & 28,965 \\
5 & Institut Pertanian Bogor & 1,339 & 6,894 & 73,500 \\
6 & Universitas Brawijaya & 2,039 & 5,347 & 34,499 \\
7 & Universitas Diponegoro & 1,663 & 5,196 & 40,033 \\
8 & Universitas Sebelas Maret & 1,616 & 5,023 & 18,936 \\
9 & Universitas Hasanuddin & 1,789 & 4,766 & 28,523 \\
10 & Universitas Sumatera Utara & 1,264 & 4,198 & 18,894 \\
\hline
\end{tabular}

Table 2. Publication ratio from the top 10 affiliation in Indonesia [1]

\begin{tabular}{cccc}
\hline No & Affiliation & $\begin{array}{c}\text { Publication ratio per year } \\
(2006-2020)\end{array}$ & $\begin{array}{c}\text { Publication ratio per year } \\
\text { (last three years) }\end{array}$ \\
\hline 1 & Universitas Indonesia & 0.61 & 1.54 \\
2 & Institut Teknologi Bandung & 0.76 & 1.39 \\
3 & Universitas Gadjah Mada & 0.32 & 0.66 \\
4 & Institut Teknologi Sepuluh Nopember & 0.52 & 1.38 \\
5 & Institut Pertanian Bogor & 0.36 & 0.74 \\
6 & Universitas Brawijaya & 0.18 & 0.50 \\
7 & Universitas Diponegoro & 0.22 & 0.65 \\
8 & Universitas Sebelas Maret & 0.22 & 0.74 \\
9 & Universitas Hasanuddin & 0.18 & 0.54 \\
10 & Universitas Sumatera Utara & 0.23 & 0.84 \\
\hline
\end{tabular}

There has been an increase in publication ratio in the last three years, this can be understood because there are regulations that require lecturers, especially associate professors and full professors, to publish their research in international journals indexed by Scopus or Web of Science (WoS). However, if calculated from 2006 , it is certain that the ratio of publications per year is not optimal. In other words, the ratio of publications is still very low. Departing from this problem, this study aims for a contribution in the form of a framework that can be used as the main alternative in optimizing research productivity, including the number of publications in higher education institutions. Before going any further, this study would like to present related research that discusses the mechanism for research productivity enhancement. Several related studies include discussing how to create a model or framework for academic research which consists of three main indicators: person, organizational, and technological aspects. The idea is how to increase research productivity using the proposed framework. The proposed framework has a conceptually good formula but has not shown the results of hypothesis testing. Some articles that discuss the mechanism for research productivity enhancement are shown in Table 3.

Table 3. The related publication discusses the mechanism of research productivity enhancement

\begin{tabular}{|c|c|c|}
\hline No & Contribution & Author(s) \\
\hline 1 & Some alternative ideas that used to enhance research productivity & Silver [2] \\
\hline 2 & Things junior staff can do to enhance the research productivity & Uncles [3] \\
\hline 3 & $\begin{array}{l}\text { Guide and direct Predoctoral Fellowships in improving research } \\
\text { productivity }\end{array}$ & Olson and Connelly [4] \\
\hline 4 & $\begin{array}{l}\text { Conducted studies on research productivity at several faculties at } \\
\text { public universities in Kenya }\end{array}$ & $\begin{array}{l}\text { Nafukho, Wekullo, and } \\
\text { Muyia [5] }\end{array}$ \\
\hline 5 & $\begin{array}{l}\text { Perform bibliometric analysis focus on scientific publication } \\
\text { productivity }\end{array}$ & Kokulu, Mutlu, and Sert [6] \\
\hline 6 & $\begin{array}{l}\text { Proposed a framework based on knowledge sharing: The role of } \\
\text { academics in increasing research productivity }\end{array}$ & Fauzi, et al. [7] \\
\hline 7 & $\begin{array}{l}\text { Sharing experiences as a researcher or academics to enhance } \\
\text { publications and research }\end{array}$ & Zain, et al. [8] \\
\hline 8 & $\begin{array}{l}\text { The use of research collaboration to enhance scientific writing and } \\
\text { scientific publication }\end{array}$ & Li, et al. [9] \\
\hline 9 & $\begin{array}{l}\text { The use of the triple-helix model to increase faculty research } \\
\text { productivity }\end{array}$ & Chanthes [10] \\
\hline 10 & $\begin{array}{l}\text { Proposed Sims model to increase research productivity in higher } \\
\text { learning institutions }\end{array}$ & Aithal [11] \\
\hline 11 & $\begin{array}{l}\text { Exploration and study of research collaboration among faculty- } \\
\text { students in increasing research productivity - student publications }\end{array}$ & $\begin{array}{l}\text { Morales, Grineski, and } \\
\text { Collins [12] }\end{array}$ \\
\hline
\end{tabular}


Table 4 shows the comparison of the type of article, the source of data, and the results obtained by each researcher. The results of the comparison show that topics related to research productivity enhancement are still very relevant and discussed by many researchers. The type of article is distributed equally in research papers, review papers, and essay papers. For the source of data, the method of observation, questionnaire, and survey still dominates. Some take data from secondary sources, namely online databases. The results obtained some of the new articles in the form of initial ideas or strategies, and others are already in the form of a model or framework.

Table 4. The comparison of the type of article, source of data, and the result obtained by each researcher

\begin{tabular}{|c|c|c|c|c|c|c|c|c|c|c|}
\hline \multirow[b]{2}{*}{ No } & \multirow[b]{2}{*}{ Author } & \multicolumn{3}{|c|}{ Type of article } & \multicolumn{3}{|c|}{ Source of data } & \multicolumn{3}{|c|}{ Result obtained } \\
\hline & & Review/survey & Research & Essays & Interview & $\begin{array}{l}\text { Observation } \\
\text { /QNR/survey }\end{array}$ & $\begin{array}{c}\text { Online } \\
\text { database }\end{array}$ & Idea & Model & Framework \\
\hline 1 & [2] & & & $\sqrt{ }$ & & $\sqrt{ }$ & & $\sqrt{ }$ & & \\
\hline 2 & [3] & & & $\sqrt{ }$ & & $\sqrt{ }$ & & $\sqrt{ }$ & & \\
\hline 3 & [4] & & $\sqrt{ }$ & & $\sqrt{ }$ & $\sqrt{ }$ & & $\sqrt{ }$ & & \\
\hline 4 & [5] & & $\sqrt{ }$ & & & & $\sqrt{ }$ & & $\sqrt{ }$ & \\
\hline 5 & [6] & & $\sqrt{ }$ & & & & $\sqrt{ }$ & & & \\
\hline 6 & [7] & & $\sqrt{ }$ & & & $\sqrt{ }$ & & & & $\sqrt{ }$ \\
\hline 7 & [8] & $\sqrt{ }$ & & & $\sqrt{ }$ & & & $\sqrt{ }$ & & \\
\hline 8 & [9] & $\sqrt{ }$ & & & & $\sqrt{ }$ & & $\sqrt{ }$ & & \\
\hline 9 & [10] & & $\sqrt{ }$ & & $\sqrt{ }$ & $\sqrt{ }$ & & & $\sqrt{ }$ & \\
\hline 10 & [11] & & $\sqrt{ }$ & & & & $\sqrt{ }$ & & $\sqrt{ }$ & \\
\hline 11 & [12] & & $\sqrt{ }$ & & & $\sqrt{ }$ & & & $\sqrt{ }$ & \\
\hline
\end{tabular}

After the study of the mechanism for research productivity enhancement in related publications, the researcher finds another way to increase the motivation of lecturers while maintaining good behavior, that is using design or elements taken from games. This initial framework is the development of a study that has done previously [13], [14]. The term use of design games as a solution to the problem of non-games context is called gamification [15], [16]. Gamification has been discussed by some researchers as a motivation boasters or solutions to problems outside of games [17]-[19]. Saputro, et al. [20] used the gamification framework to enhance students' intrinsic motivation on massive open online courses. The next part will focus on the elements or design games that will be used as constructs from the initial framework. Table 5 shows some alternative games design that can be used as constructs.

Table 5. The games designs can be used as a construct

\begin{tabular}{cll}
\hline No & \multicolumn{1}{c}{ Games design } & \multicolumn{1}{c}{ References } \\
\hline 1 & Teamwork, competition, network & {$[20]-[22]$} \\
2 & Virality, mission, countdowns, goals & {$[20],[23],[24]$} \\
3 & Skill, ability, status & {$[20],[25]$} \\
4 & Level, points, badges, progress bar & {$[26]-[28]$} \\
\hline
\end{tabular}

\section{RESEARCH METHOD}

This study began with problem identification and then literature review, understanding several related publications discussed research productivity enhancement. The purpose of this review literature is to find research opportunities among the research conducted. These opportunities can be in the form of discovery, integration, or improvement of preexisting methods. Then the research hypothesis is determined as a construct that will be used to build the framework. The next step is to determine the instruments to be used for the pilot test needs. Pilot tests are used to determine the validity and reliability of the constructs used in the framework. As input for the pilot test required data obtained from correspondents through an online questionnaire. Data obtained through a questionnaire are sorted, to obtain relevant data. Finally, an analysis and discussion of the results of the pilot test were carried out. Figure 1 shows the overall research procedure. 


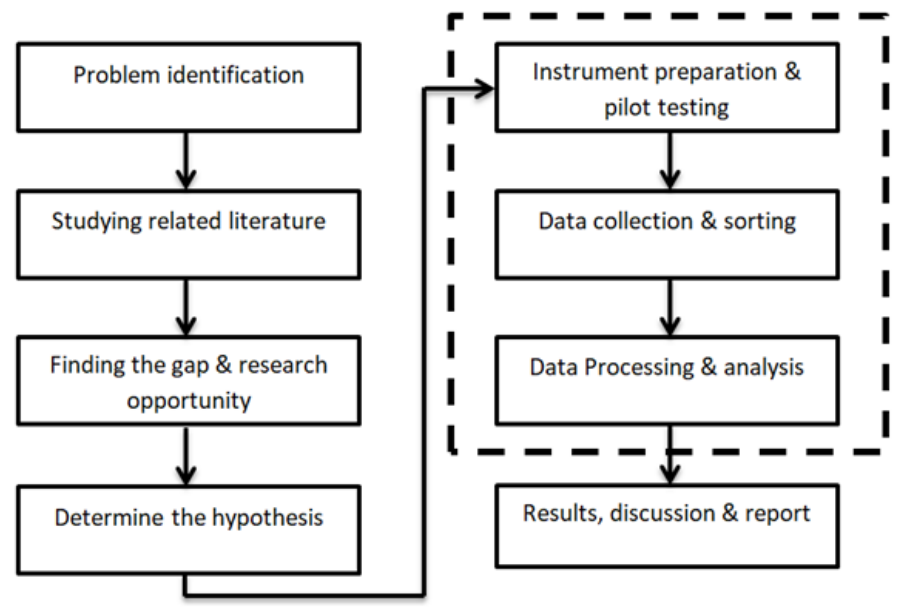

Figure 1. The research procedure

The sample data used were collected from Universitas Indo Global Mandiri lecturers in Palembang, Indonesia. The data were obtained through an online questionnaire, which began in early 2020. Partial Least Square-Structure Equation Modelling (PLS-SEM) used for testing, and analysis of the proposed framework [29]-[31]. The reason why the SEM method is chosen is that it supports complex modeling constructs with minor correspondents. SEM is effective in modeling latent variables, measuring error correction and estimating parameters for all hypotheses simultaneously. PLS-SEM is an alternative method of modeling equation structure used to describe the relationships between constructs, emphasizing the theory of the value of these relationships with a small sample data size.

\section{RESULTS AND DISCUSSION}

Based on the game design in Table 5, the next step is to select the construct that will be used in the proposed framework. But before determining the construct, the next step is to formulate the research hypothesis $(\mathrm{H})$ as the initial step in building the framework.

H1: The teamwork [20]-[22] has a positive effect on academics' behavior towards the enhancement of research productivity. The teamwork can be interpreted as cooperation between members in a team that is complementary to achieve mutually agreed goals.

H2: The network [20]-[22] has a positive effect on academics' behavior towards the enhancement of research productivity. The network is a relationship between two or more objects that are interconnected to achieve certain goals.

H3: The competition [20]-[22] has a positive effect on academics' behavior towards the enhancement of research productivity. The competition is a competition between two or more individuals/groups.

H4: The points [26]-[28] have a positive effect on academics' motivation towards the enhancement of research productivity. The point is a size that is usually in nominal form.

H5: The goals [20], [23], [24] has a positive effect on academics' motivation towards the enhancement of research productivity. The goal is something to be achieved in the future.

H6: The leveling up [26]-[28] has a positive effect on academics' motivation towards the enhancement of research productivity. The level is a tool to measure achievements with agreed height heights. productivity.

H7: Good behavior among academics' will have a positive effect on the enhancement of research

H8: The high motivation for academics' will have a positive effect on the enhancement of research productivity. Based on the hypotheses explained, the initial framework proposed is as shows in Figure 2. 


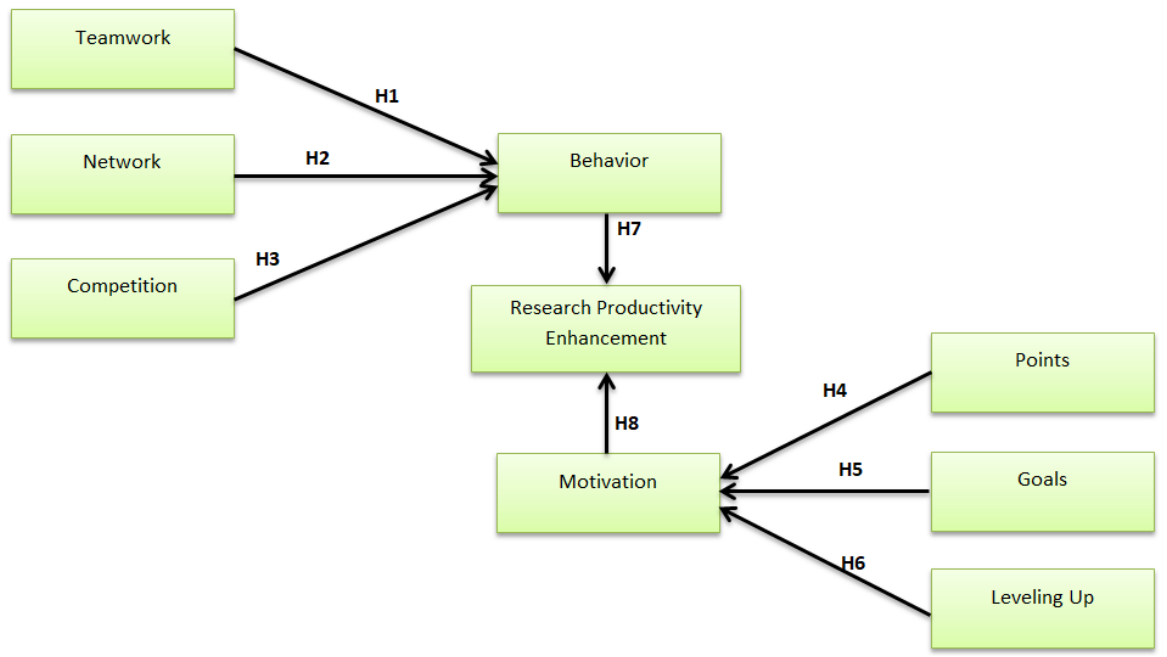

Figure 2. The initial framework

The idea of this framework is to increase the motivation of lecturers while maintaining good behavior, shown in Figure 2. This model framework consists of six independent variables and three dependent variables. Networks, teamwork, competition, points and leveling-up are the independent variables. The dependent variable used is the behavior and motivation of academics, and the research productivity enhancement. The testing results of the proposed framework shown in Figure 3 . The outer model or loading factor value shows the validity of the indicator to a construct. If it is more than 0.7 , then the indicator is declared valid. However, there is another opinion which states that values above 0.5 have been declared valid or can still be tolerated. For example, the outer model values for each indicator i1X3, i2X3, and i3X3 are $0.932,0.929$, and 0.877 then these three indicators are declared valid.

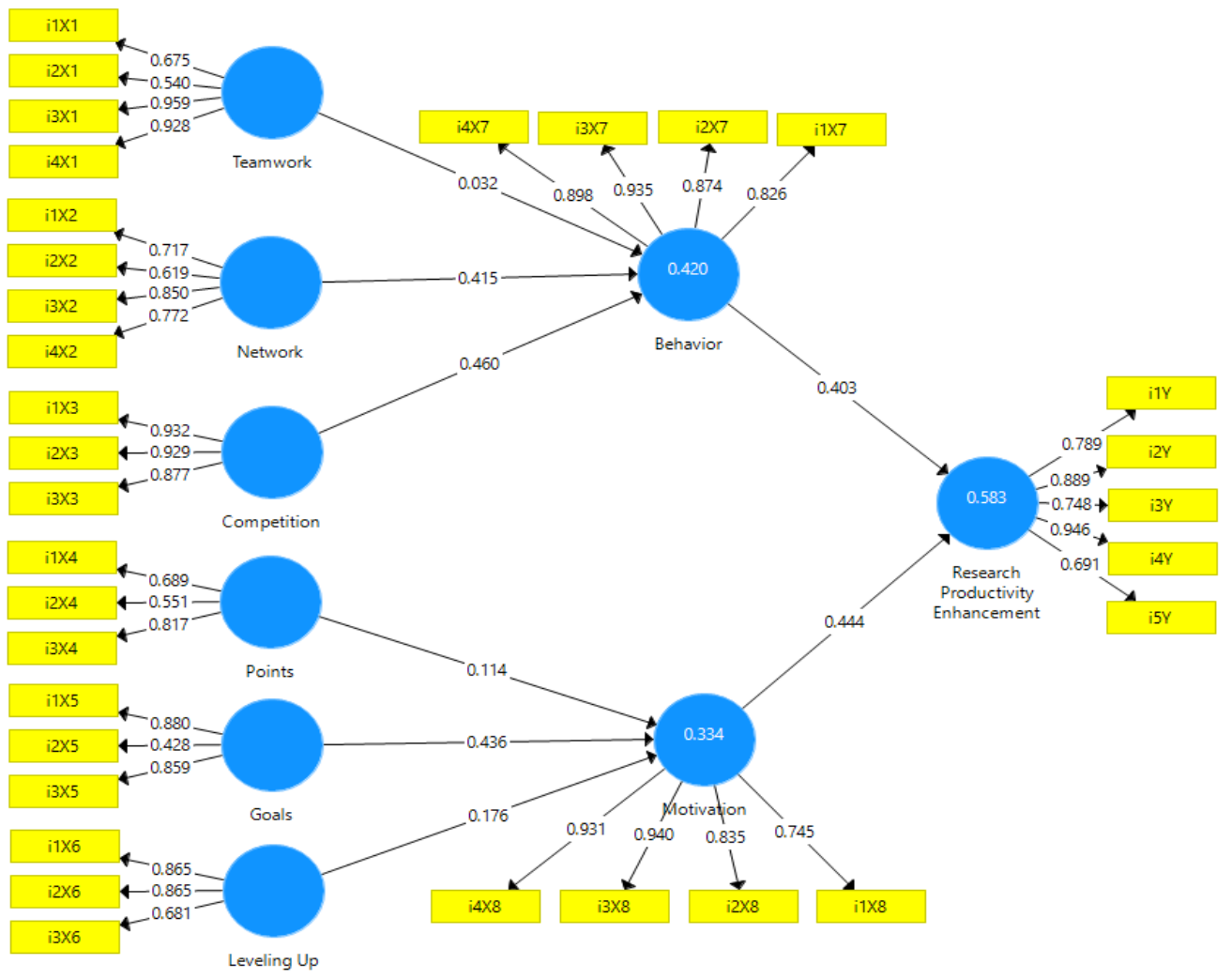

Figure 3. The pilot test for the proposed framework 
Overall, there is only one indicator with a value below 0.5 , i2X5. Furthermore, the Regression coefficient between constructs shows whether a construct has a positive effect. The Network variable coefficient value of 0.415 shows that the Network has a positive effect on academics' behavior. A value of 0.403 shows that behavior among academics' has a positive effect on the enhancement of research productivity. Because Network and Behavior among academics has a positive effect, then will be used in the proposed framework in the future. Conversely, if there is a variable that has a negative effect, it must be replaced or analyzed further. For details, the effect of each construct on other constructs shown in Table 6.

Table 6. The effect of each construct

\begin{tabular}{ccccc}
\hline No & Construct & Toward & Value & Effect \\
\hline 1 & Behavior & Research productivity enhancement & 0.403 & Positive \\
2 & Competition & Behavior & 0.460 & Positive \\
3 & Goal & Motivation & 0.436 & Positive \\
4 & Leveling up & Motivation & 0.176 & Positive \\
5 & Motivation & Research productivity enhancement & 0.444 & Positive \\
6 & Network & Behavior & 0.415 & Positive \\
7 & Points & Motivation & 0.114 & Positive \\
8 & Teamwork & Behavior & 0.032 & Positive \\
\hline
\end{tabular}

Then discriminant validity testing is done using the Average Variance Extracted (AVE) root value of each construct. If the AVE root value is above 0.5 , it can be concluded that the construct has a good convergent validity value. For reliability testing using Composite reliability (CR) and Cronbach alpha (CA), for each construct if it is greater than 0.6 indicates that it already has a good reliability value as shown in Table 7.

Table 7. AVE, CR, and CA

\begin{tabular}{ccccc}
\hline No & Construct & AVE & CR & CA \\
\hline 1 & Behavior & 0.782 & 0.935 & 0.907 \\
2 & Competition & 0.833 & 0.937 & 0.900 \\
3 & Goal & 0.565 & 0.783 & 0.614 \\
4 & Leveling up & 0.653 & 0.848 & 0.761 \\
5 & Motivation & 0.751 & 0.923 & 0.891 \\
6 & Network & 0.554 & 0.831 & 0.759 \\
7 & Points & 0.482 & 0.731 & 0.543 \\
8 & Research productivity enhancement & 0.669 & 0.909 & 0.872 \\
9 & Teamwork & 0.632 & 0.867 & 0.816 \\
\hline
\end{tabular}

If the AVE, CR, and CA values for other constructs have good reliability, but not for Points. For the AVE value of 0.482 and CA of 0.543 . Although it is almost close to the minimum threshold, it should be a question. Need an adjustment for indicators from the Points that will be used next. Because some indicators in the Points variable are still rarely used or are not yet familiar in the higher education institution environment, or have been used but with different terms. So as to offer an understanding to lecturers about the use and function of Points in determining research productivity performance in higher education, more testing, and analysis needed in future work.

\section{CONCLUSION}

Based on the preliminary testing of the proposed framework, it shows that each construct of the framework has a positive impact on research productivity enhancement as the final goal to be achieved. High motivation and good behavior are needed for research productivity enhancement. As shown in the pilot test, both of these constructs have a high positive impact value on research productivity enhancement. Although the value of AVE for the Points does not have good discriminant validity. While for the reliability test, Composite reliability (CR) shows that all variables have good reliability. In contrast to CR, the Cronbach alpha (CA) test results show the Points is also not reliable to be used as constructs in the proposed framework, it will become homework in the future study. 


\section{ACKNOWLEDGEMENTS}

This work was supported by a grant from the Ministry of Research and Technology of the Republic of Indonesia (Kemenristek/BRIN Republic of Indonesia).

\section{REFERENCES}

[1] Ministry of Research and Technology of the Republic of Indonesia, "Top 100 Affiliations," SINTA2.RISTEKBRIN.go.id. [Online]. Available: https://sinta.ristekbrin.go.id/ (accessed Feb. 25, 2020).

[2] E.A. Silver, "Some ideas on enhancing research productivity," International Journal of Production Economics, vol. 118, no. 1, pp. 352-360, 2009, doi: 10.1016/j.ijpe.2008.08.037.

[3] M. Uncles, "What Can Be Done to Enhance the Research Productivity of Junior Staff?" Australasian Marketing Journal (AMJ), vol. 8, no. 2, pp. 73-79, 2000, doi: 10.1016/S1441-3582(00)70194-7.

[4] R.K. Olson and L.M. Connelly, "Mentoring Through Predoctoral Fellowships to Enhance Research Productivity," Journal of Professional Nursing, vol. 11, no. 5, pp. 270-275, 1995, doi: 10.1016/S8755-7223(05)80007-9.

[5] F.M. Nafukho, C.S. Wekullo, and M.H. Muyia, "Examining research productivity of faculty in selected leading public universities in Kenya," International Journal of Education Development, vol. 66, pp. 44-51, 2019, doi: 10.1016/j.ijedudev.2019.01.005.

[6] K. Kokulu, H. Mutlu, and E.T. Sert, "Scientific Publication Productivity of Emergency Physicians: A Bibliometric Analysis of The Last Decade," The Journal of Emergency Medicine, vol. 57, no. 1, pp. 13-20, 2019, doi: 10.1016/j.jemermed.2019.03.021.

[7] M.A. Fauzi, C.N. Tan, R. Thurasamy, and A.O. Ojo, "Knowledge sharing: Role of academics towards research productivity in higher learning education," VINE Journal of Information and Knowledge Management Systems, vol. 49, no. 1, pp. 136-159, 2019, doi: 10.1108/VJIKMS-09-2018-0074.

[8] S.M. Zain, et al., "Motivation for Research and Publication: Experience as a Researcher and an Academic," Procedia - Social and Behavioral Sciences, vol. 18, pp. 213-219, 2011, doi: 10.1016/j.sbspro.2011.05.030.

[9] G. Li, et al., "Enhancing research publications and advancing scientific writing in health research collaborations: Sharing lessons learnt from the trenches," Journal of Multidisciplinary Healthcare, vol. 11, pp. 245-254, 2020, doi: 10.2147/JMDH.S152681.

[10] S. Chanthes, "Increasing Faculty Research Productivity via a Triple-Helix Modeled University Outreach Project: Empirical Evidence from Thailand," Procedia - Social and Behavioral Sciences, vol. 52, pp. 253-258, 2012, doi: 10.1016/j.sbspro.2012.09.462.

[11] P. S. Aithal, "How To Increase Research Productivity In Higher Education Institutions-SIMS Model," International Journal of Scientific Research and Modern Education, vol. 1, no. 1, pp. 447-458, 2016.

[12] D.X. Morales, S.E. Grineski, and T.W. Collins, "Increasing Research Productivity in Undergraduate Research Experiences: Exploring Predictors of Collaborative Faculty-Student Publications," CBE Life Sciences Education, vol. 16, no. 3, 2017, doi: 10.1187/cbe.16-11-0326.

[13] A. Sanmorino, Ermatita, and Samsuryadi, "The Preliminary Results of the Kms Model with Additional Elements of Gamification to Optimize Research Output in a Higher Education Institution," International Journal of Engineering and Advanced Technology, vol. 8, no. 5, pp. 554-559, 2019.

[14] A. Sanmorino, Ermatita, Samsuryadi, and D. P. Rini, "A Robust Framework using Gamification to Increase Scientific Publication Productivity," Proc. - 2nd Int. Conf. Informatics, Multimedia, Cyber, Inf. Syst. ICIMCIS 2020, pp. 29-33, 2020, doi: 10.1109/ICIMCIS51567.2020.9354319.

[15] S. Deterding, M. Sicart, L. Nacke, K. O'Hara, and D. Dixon, "Gamification using game-design elements in nongaming contexts," in CHI'11 Extended Abstracts on Human Factors in Computing Systems, pp. 2425-2428, 2011, doi: $10.1145 / 1979742.1979575$.

[16] H. Setiana and S. Hansun, "Gamified Android-Based Academic Information System," Int. J. Eval. Res. Educ. (IJERE), vol. 6, no. 2, p. 164, 2017, doi: 10.11591/ijere.v6i2.7595.

[17] K. Werbach and D. Hunter, How game thinking can revolutionize your business. Wharton Digital Press, Philadelphia, 2012.

[18] R.N. Landers and A.K. Landers, "An empirical test of the theory of gamified learning: The effect of leaderboards on time-on-task and academic performance," Simulation \& Gaming, vol. 45, no. 6, pp. 769-785, 2014

[19] C. Dichev, D. Dicheva, G. Angelova, and G. Agre, "From gamification to gameful design and gameful experience in learning," Cybernetics and Information Technologies, vol. 14, no. 4, pp. 80-100, 2014, doi: 10.1515/cait-20140007.

[20] R.E. Saputro, S. Salam, M. H. Zakaria, and T. Anwar, "A gamification framework to enhance students' intrinsic motivation on MOOC," TELKOMNIKA Telecommunication, Computing, Electronics and Control, vol. 17, no. 1, pp. 170-178, 2019, doi: 10.12928/telkomnika.v17i1.10090.

[21] I. Buchem, A. Merceron, J. Kreutel, M. Haesner, and A. Steinert "Gamification designs in Wearable enhanced learning for healthy ageing," International Conference of Interactive Mobile Communication Technologies and Learning, 2015, pp. 9-15.

[22] R.A. Saraguro-Bravo, D.I. Jara-Roa, and M. Agila-Palacios, "Techno-instructional application in a MOOC designed with gamification techniques," in 20163 rd International Conference of eDemocracy eGovernment ICEDEG, 2016, pp. 176-179.

[23] S. Schacht, S. Morana, and A. Maedche, "The Project World - Gamification in Project Knowledge Management," in 22nd European Conference on Information Systems, 2014. 
[24] M. Schacht and S. Schacht, "Start the Game: Increasing User Experience of Enterprise Systems Following a Gamification Mechanism," Software for People. Management for Professionals, A. Maedche, A. Botzenhardt, and L. Neer, Ed., Springer Berlin Heidelberg, 2012, pp. 181-199, doi: 10.1007/978-3-642-31371-4_11.

[25] A. Hansch, C. Newman, and T. Schildhauer "Fostering Engagement with Gamification: Review of Current Practices on Online Learning Platforms," HIIG Discussion Paper Series No. 2015-04, 2015. [Online]. Available: https://ssrn.com/abstract=2694736.

[26] C. Meinel, M. Totschnig, and C. Willems, "openHPI: Evolution of a MOOC Platform from LMS to SOA," in Proceedings of the 5th International Conference on Computer Supported Education (CSEDU), INSTICC. Aachen, 2013, pp. 593-598.

[27] C. Willems, et al., "Motivating the Masses-Gamified Massive Open Online Courses on Openhpi," in EDULEARN14 Proceedings, 2014, pp. 4042-4052.

[28] T. Staubitz, et al., "The gamification of a MOOC platform," in Global Engineering Education Conference (EDUCON), IEEE, pp. 883-892, 2017.

[29] J.F. Hair, C.M. Ringle, and M. Sarstedt, "PLS-SEM: Indeed a Silver Bullet," Journal of Marketing Theory and Practice, vol. 19, no. 2, pp. 139-152, 2011, doi: 10.2753/MTP1069-6679190202.

[30] L. Law and N. Fong, "Applying partial least squares structural equation modeling (PLS-SEM) in an investigation of undergraduate students' learning transfer of academic English,” J. English Acad. Purp., vol. 46, p. 100884, 2020, doi: 10.1016/j.jeap.2020.100884.

[31] N. P. Danks, P. N. Sharma, and M. Sarstedt, "Model selection uncertainty and multimodel inference in partial least squares structural equation modeling (PLS-SEM)," J. Bus. Res., vol. 113, no. March, pp. 13-24, 2020, doi: 10.1016/j.jbusres.2020.03.019. 